\title{
Parish Councils and the Libraries Acts.
}

T HAVE been requested by several members to read a paper on the Legislation which has taken place since we last met, affecting Public Libraries and their management, and particularly on the effect of the Parish Councils Act. Before dealing with that important statute, our English friends will not object, I am sure, to a reference to the new Irish and Scotch Acts, which are really the only Acts of the past Session exclusively relating to Public Libraries.

The Public Libraries (Ireland) Acts Amendment Act, I894, is not all that might have been expected for the fair sister isle. True, it makes important changes, but if Consolidating Acts were requisite for Scotland in 1887 , and England and Wales in I892, Ireland in 1894 , was, I think, fairly entitled to an Amending and Consolidating Act, and not a mere amendment of the old Act of 1855 .

Section 4 of that Act is repealed by the statute now under consideration. That section provided for the adoption of the Act in any incorporated borough or town having a population of 5,000 persons, by two-thirds of the householders present at a public meeting. The Amending Act of 1877 (which, by the way, does not appear to be repealed) authorised the adoption, either by the public meeting or by the issue of voting papers to the ratepayers, and the decision of a mere majority was to be sufficient. The area for the adoption of the principal Act is to be the urban district, and this is defined as meaning an incorporated borough or a town, as defined by the principal Act. The Committee appointed to consider the Bill appear to have had considerable difficulty in adopting a suitable area, and though it rejected the proposal to extend the Act to rural districts, it

\footnotetext{
- Read before the I $7_{\text {th }}$ Annual Meeting of the Library Association, Belfast, September, 1894.
} 
would appear that the population limit in the towns has been removed. The old method of adoption goes with the repeal of section 4 of the Act of 1855 , and henceforth the urban authority may adopt the Act by passing the necessary resolution in accordance with the regulations, and subject to the publication, prescribed by the new Act. This is the principle adopted for urban districts in England by the Act of 1893 , but the Irish Act contains a necessary and useful proviso to the effect that if the urban authority fail to pass a resolution adopting the Act, any twenty or more ratepayers in the district may require the mayor or chairman to ascertain the opinion of the voters on the question of adoption, or the limitation of the rate, and this is to be ascertained not by voting papers but by ballot, the Local Government Board being authorised to make any rules for carrying into effect the object of the Act. The poll will be taken of the voters in the district, i.e., the Parliamentary voters (owners, occupiers and lodgers), and freemen (in boroughs). The majority of answers is to decide any question. It is unnecessary to refer in detail to the Act which will, no doubt, ere long be in the hands of all the members; but some points call for observation. Thus, if a poll is taken and the Act is adopted, the urban authority is to carry it into execution. Should they fail in their duty, the Local Government Board, on the application of ten or more voters, are to appoint from among the voters five Commissioners to carry the principal Act into execution, who will have all the powers of the urban authority under the Act. The authorities of two or more neighbouring (not necessarily adjoining) districts may, after the adoption of the Act, combine for any period for carrying the Act into execution; or they may make an agreement to share the cost of the purchase, erection, repair and maintenance of any library (including a museum, school of science, art gallery, or school for art) situate in one of the districts. There is a power to let any part of the premises not required for the Act, which may prove useful where it is necessary to provide a source of income from rents for portions let for business or other purposes. Section 9 authorises an authority to accept any grant from the science and art department towards the purchase of the site, or the erection, enlargement, or repair of any school of science or art, or other purpose for which a grant may be made. It is to be hoped that this short but useful measure will result in an extension of the free library movement in Ireland. 
The next Act to be noticed is the Public Libraries (Scotland) Act, 1894. This Act relates entirely to the adoption of the principal Act in burghs. Sections 4, 5, and 6 of the Consolidating Act of 1887 prescribe that its adoption shall only take place by a majority of the householders voting - to be ascertained by means of voting papers. Section 5 enacted that if a majority determined against the adoption, the question was not to be raised for two years. Henceforth in burghs the magistrates and Council are alone authorised to adopt the Act by a resolution to be passed after due notice, and published as prescribed. If the proposition is not adopted, there is now no limit of time within which it may not again be brought forward. A copy of the Act has already appeared in the LiBrARY, and has been circulated among the members.

Lastly, I must refer to the Local Government, or as it is popularly described, the Parish Councils Act, r894. This statute has, by what may be called a side-wind, made some important changes in the English law relating to Free Public Libraries and Museums. At the risk of being wearisome, I must refer to this statute in detail, as I have seen no attempt to extract from its complicated provisions the effect which it will exercise in future upon library work. I shall, of course, be understood as referring simply to the relation of the Act to the Public Libraries Act, I892.

Section 7 declares that from the appointed day in every rural parish, the parish meeting shall exclusively have the power of adopting the Public Libraries Act, 1892, including any acts amending the same. The "appointed day" is a convenient but vague expression. In some parishes (i.e., such as are to have no Parish Council), this will be the 8th November next, or such later date in the present year as the Local Government Board fix. In others (i.e., where a Parish Council is to be elected), it will be the second Thursday next after the election of the Parish Council, on which day that body comes into office. I make this statement with hesitation, preferring to refer any interested members to section 84 of the Act, which is supposed to define the expression. I can say no more than that I hope I have interpreted the meaning of the section so far as it relates to the adoptive acts.

The parish meeting is to consist of the parochial electors (an entirely new creation), who may be described as the County Council electors (occupiers), Parliamentary electors (owners and 
lodgers), and married women, is., such as have the necessary qualification to be enrolled on the parochial electors' list. Each elector has one vote and no more. The majority of the electors present and voting at the meeting decides the question in the first instance, and the chairman's decision as to the result is to be final, unless a poll is demanded, which may be done by any one parochial elector. Such poll is to be taken by ballot, and subject to rules to be framed by the Local Government Board. Presumably the chairman of the parish meeting is to cause the poll to be taken, but he does not appear to be directly required to do so, nor does he commit any offence should he fail. The expenses of the meeting and of the poll are to be paid out of the Poor Rate, but as regards the poll, they are not to exceed the scale to be adopted by the County Council, or on their default by the Local Government Board. Thus, by a few words the whole system of ascertaining the opinion of the voters by voting papers (approved so recently as 1892), is abolished as regards rural parishes, following its abolition in urban districts in 1893 , and leaving it to flourish in metropolitan districts only. At the same time there is a reversion to the principle recognised by the Act of 1855 , for the adoption of the Act by the inbabitants at a public meeting, as also a considerable extension of the electorate who are to decide the questions submitted to them. The section applies not merely to the question of adoption, but also to the limitation of expenditure. The result is most confusing and complicated; thus, in London there will be one system for adoption, in urban districts another, and in rural parishes another; the same observations applying to the same districts as regards the persons who are to vote. In the County of London they will be the County electors, in the urban districts the urban authority to the exclusion of the electors, and in rural parishes the parochial electors.

Section 7, sub-section 4, provides that where under the Act the consent or approval, or other act on the part of the vestry of a rural parish is required, in relation to any expense or rate, the Parish Meeting is to be substituted for the vestry, and for this purpose the expression "vestry" shall include any meeting of ratepayers or voters. This effects a complete alteration of many sections in the principal Act and will raise considerable doubt. To explain it would necessitate the quotation of all the sections where vestries are referred to in the Public Libraries Act, I892, c.g., section 5 (Constitution of Commissioners for 
executing Act in Parish), section 9 (power of neighbouring parishes to combine), section to (power to annex parish to adjoining district), and several others; but the chief difficulty lies in interpreting the sections where references are made to the voters. Is the Parish Meeting, or are the parochial electors to be understood in the future as the voters referred to in the principal Act ? Observe that vestry means any meoting of voters. Frequently the assent of the voters is required, but not at a meeting. These and other difficulties might have been obviated if the promoters had consulted those who have had practical experience of the Acts they propose to tinker, and at least the Council of the Association might have been approached on this part of the Act.

Sub-section 5 of the same section puts an end to existing Commissioners in rural parishes, where Parish Councils are elected. It provides that where the area under any existing authority, acting within a rural parish in the execution of the Public Libraries Act is co-extensive with the parish, all powers, duties, and liabilities of that authority, shall, on the Parish Council coming into office, be transferred to that Council. And sub-section 7 is not less important. It enacts that when after the appointed day the Act is adopted for a rural parish, and the parish has a Parish Council, that Council is to be the authority for the execution of the Act. In rural parishes where Parish Councils are not elected, it would appear that existing Com. missioners continue to be the authority, and in case the Act is adopted in any such parish, the Parish Meeting would have to appoint Commissioners, but this is not at all clear, for while by section 7 the Parish Meeting has to adopt the Act, by section Ig (3), it is provided that the meeting may appoint a committee of their own number for any purposes which would be better regulated and managed by such a committee, and the legal interest in all property, which, if there were a Parish Council, would vest in that Council, is to vest in the chairman and over. seers. On the other hand the sections in the Public Library Act authorising the appointment of Commissioners are not repealed. But these parishes will be few in number, as all parishes having a population of 300 must, and of from 100 to 300 may elect a Parish Council, while even parishes having a population of less than 100, may obtain power from the County Council to elect a Parish Council. Whether the new Councils will be more suitable for carrying on library work in rural 
parishes remains to be seen. The multiplication of authorities for carrying various Acts into effect, is as a rule fraught with unnecessary expense, and in this respect the simplification effected by the Act is to be commended. It seems probable that the section will result in the wider adoption of the principal Act, especially if the scheme of travelling villa ge libraries were practically accomplished in each county.

Section II is intended as a safeguard against extravagance on the part of the Parish Council. Thus before incurring expenses which would involve a rate exceeding threepence in the pound, they must obtain the approval of a Parish Meeting. If they wish to borrow money the County Council and Local Government Board must give their consent, and in any event their expenses must not exceed sixpence in the pound for any year. But this does not include expenses under the Adoptive Acts, which are to be shown separately on the demand note. In parishes where there is no Parish Council, the rate when added to the expenses under any of the Adoptive Acts is not to exceed sixpence in the pound.

Section 57 authorises the appointment out of their respective bodies of a joint Committee by two or more Parish Councils.

So far, we have been discussing rural parishes only. But the Act by no means stops at them. Urban districts, and even the metropolis, come within its scope. Section 62 provides that an Urban District Council may resolve that the powers, \&c., of any existing authority acting in the urban district shall be transferred to such Council, and thereupon the authority is to cease to exist. This is, perhaps, limited to a very few cases, since the Urban Authority as a rule executes the Act in urban districts, and the further provision that the Act is not to be adopted for any part of an urban district without the approval of the District Council is of no importance, as the Act cannot be adopted for part of such a district. In my opinion this does not apply to the metropolis.

But section 33 applies to the administrative county of London, county boroughs, ordinary boroughs, and urban districts, and it authorises the Local Government Board on the application of the Council (or in the case of London of the Sanitary Authority), or any representative body, to make an order conferring on the Council, Sanitary Authority, or other representative body within the borough, all or any of the powers, duties, or liabilities of a Parish Council. 
This would include the transfer under section 7 , sub-section 5, of the powers, duties, and liabilities of any existing authority (6.g., Library Commissioners), acting within the parish, and under sub-section 7, the execution of the Act where it is hereafter adopted. That this was intended or contemplated by the promoters, seems to be very doubtful, and possibly the Local Government Board would not be disposed to grant such an application. At any rate, it may be presumed that no transfer will be made without consulting the existing library authority, but it must be pointed out and borne in mind that the tendency of legislation (and rightly so, I think) is in the direction of reducing the number of authorities exercising statutory jurisdiction in a district, but it is open to the possible objection that the Committee would have to be composed entirely of members of the Council or Sanitary Authority to the serious loss, in many cases, of valuable service from co-optative members who are now appointed under the Public Libraries Act because of their interest in library work.

Recent legislation has not been marked by that clearness of language and effect which in these days might reasonably be expected to prevail, and the Local Government Act, 1894 , forms no exception to the rule. In some cases it is hopeless to attempt to understand or explain it, and I conclude this paper with a protest against tinkering Acts of Parliament by side-winds in a general Act relating to entirely different subjects, and without the slightest consideration of the effect it will have upon all the provisions of the Act it seeks to "amend."

H. W. Fovargur.

Town Hall, Eastbourms. 